\title{
Managing Water Resources in Large River Basins
}

\author{
William Young * and Nagaraja Rao Harshadeep \\ World Bank, 1818 H Street, Washington, DC 20006, USA; harsh@worldbank.org \\ * Correspondence: wyoung@worldbank.org
}

Received: 8 December 2020; Accepted: 10 December 2020; Published: 11 December 2020

The management of water resources in large rivers basins commonly involves challenges and complexities that are not found or are less common in smaller basins. Irrespective of size, issues of infrastructure construction and operation, irrigation and drainage management, water use efficiency and flood management are common. However, larger basins commonly span multiple jurisdictions and traverse diverse bio-geographies, which often give rise to greater complexity of competing interests between sectors, environments and communities. The sustainable development of large river basins commonly requires considering both consumptive water use and non-consumptive water use (e.g., inland navigation and hydropower) and tackling large-scale drought and flood management. These challenges make long-term strategic planning arguably more important than in smaller basins, but also usually more complex in both analytical, participatory and political terms. This requires navigating both "hard" issues (e.g., infrastructure, hydromet, information technologies) as well as "soft" issues (e.g., legal frameworks, policies, institutions, participation, political economy).

There is no widely accepted hard criterion for defining "large river basins" either in terms of drainage area or total discharge. Thus, herein a loose definition is adopted that includes basins exceeding 100,000 km (of which there are an estimated 130 globally) as well as geographically smaller basins characterized by hydrologic complexity (e.g., extreme variability, non-stationarity, complex surface-groundwater connectivity), water management complexity (spatiotemporal supply-demand imbalance, major water infrastructure, inter-sectoral competition, pollution, high flood risk, climate change vulnerability) and/or governance complexity (cross-jurisdictional conflict, legal and regulatory complexity).

Most of the large and highly populated river basins in the world are international transboundary basins. Of the 286 international transboundary river basins in the world (spanning 151 countries and with over 40 percent of the global population), the fourteen basins with the greatest economic dependence on water are home to nearly 1.4 billion people [1]. In these and other basins, water resources management is integral to sustainable development, and in 2015, all 193 Member States of the United Nations General Assembly agreed to the 2030 Agenda for Sustainable Development. This agenda is captured in seventeen Sustainable Development Goals (SDGs), including SDG6-Ensure availability and sustainable management of water and sanitation for all. SDG6 considers water supply and sanitation services, water scarcity and water use efficiency, water quality and wastewater treatment, water ecosystems, as well as institutional aspects of water resource management and cooperation [2]. However, coordinated, efficient and effective water resources management to deliver on SDG6 (and other water-related goals) in large basins must overcome several significant challenges, as explored in the papers in this Special Issue.

This Special Issue of Water comprises nine papers with contributions from over fifty authors that traverse the hard and soft aspects of managing water resources in large river basins through a series of diverse case studies that showcase recent advances in technological and governance innovations for large river basin management. The papers touch on many of the great rivers of the developing world — the Ayeyarwady, Brahmaputra, Ganges, Mekong and Nile—with transboundary issues highlighted as a key challenge in many large basins. 
The papers include six Research Articles (including the Special Issue Feature Paper), two Communications and one Case Report. The Feature Paper [3], by the guest co-editors, frames the Special Issue by discussing the distinguishing features and importance of large river basins, and introducing a conceptual framework for water security that connects water endowment, the water sector architecture (institutions and infrastructure), water sector performance (resource management, service delivery and risk mitigation) and the outcomes from how water is managed and used. Harshadeep and Young [3] then explore the application of a range of disruptive technologies to the different dimensions of water resource management, considering the disruption of data value chains, production value chains and stakeholder participation value chains. Importantly, the analysis also considers the different institutional roles in the disruption process and the important risks and barriers to adoption. Overall, Harshadeep and Young find that the increasing uptake of disruptive technologies has particular utility for large river basins and can help to "democratize" water management through improved access to data and information, but they note that an increased effort will be required to ensure equity in technology access.

Several papers in the Special Issue explore, in more detail, applications of key data technologies introduced by Harshadeep and Young. Dandridge et al. [4] present a case report for the use of Earth observations in water management in the Lower Mekong River Basin. Specifically, they describe the application of a downscaling algorithm to generate a $1 \mathrm{~km}$ grid for soil moisture based on the $9 \mathrm{~km}$ interpolated grid of soil moisture from the NASA active passive mission radiometer. Dandridge et al. demonstrate how these data can be applied directly to improve flood prediction and assessment, as well as to provide drought monitoring and agricultural productivity predictions for large river basins. Zhao et al. [5] approach the complexity of multiple competing objectives in large river basins by demonstrating the application of optimization techniques (based on cumulative probability distribution functions) to the operational management the reservoir cascade in the Heihe River in China. Zhao et al. quantify the trade-offs between competing objectives, enabling identification of "least worst" operating rules. Simonov et al. [6] approach the competing-uses challenge in the transboundary Amur River Basin by assessing the effectives of a range of analytical methods for considering the environmental impacts of both existing and proposed hydropower facilities. These methods include rapid strategic basin-scale impact assessments, assessments of flow regime and floodplain alteration, assessment of riverine habitat impacts, assessments of river fragmentation, identification of protected areas, and environmental flow assessments. The work shows that hydropower investment decisions need to be guided by a range of environmental impact assessments from the site to the basin scale, informed by the geographic distribution and connectivity of biodiversity hotspots, and integrated into a robust and participatory planning process.

Van der Vat et al. [7] present a case study of participatory modelling for the Ganges River Basin in India, that demonstrates the integration of Earth observations with in situ data within a basin modelling framework, coupled to a customized dashboard to support collaborative interactions and to guide basin planning decisions. While building on past modelling efforts for the Ganges, van der Val et al. present the first attempt to bring together analytical models for surface and groundwater hydrology, water quality, riverine ecology within an IWRM framework to explore the potential impacts of both future climate change and socio-economic development for the Ganges Basin. The collaborative modelling approach spanned central and multiple basin state governments, as well as NGOs and development partners. O'Sullivan et al. [8] focus specifically on the challenges of stakeholder engagement in large river basins. They present a new integrative framework for stakeholder engagement built around a cloud-based web application for basin modelling and planning that relies heavily on open access Earth observation datasets. They explore the utility of the platform through three case studies that explore irrigation development, transboundary water sharing, and environmental water allocations.

Foran et al. [9] explore stakeholder participation in large basins, putting technology to one side and exploring river basin decision making from collaborative governance and deliberative process standpoints. They make the case for co-production of knowledge and planning scenarios to improve 
the social and political legitimacy of basin planning decisions. They illustrate the approach using cases studies from the Ayeyarwady River Basin in Myanmar and the Kamala River Basin in Nepal. Despite the difficulties faced in implementing a collaborative co-production approach in these river basins, Foran et al. note that more typical bureaucratic approaches are similarly complex and yet are more contested and less likely to deliver widely accepted courses of action.

Barua et al. [10] explore the specific basin governance challenge of transboundary cooperation, focusing on options to progress cooperation in cases where political constraints preclude formal diplomacy. They explain the process and value of informal "track 2" dialogues and illustrate these with a case of a sustained four-country dialogue process in the Brahmaputra River Basin in South Asia. They demonstrate the pathways by which informal dialogue can develop a shared understanding amongst stakeholders and how this can influence basin planning and development. Gari et al. [11] investigate a formal approach to water allocation in transboundary river basins based on the principles of the United Nations' Watercourse Convention. They develop a set of potential indicators for these principles and evaluate the application of selected indicators to water allocation amongst the countries of the Nile Basin. To guide indicator selection and to assess indicator utility and acceptability, they distributed an email questionnaire to more than 200 experts from Nile basin countries and across the world. Based on questionnaire responses, they identify a subset of indicators for which there is a high level of consensus and which could provide a foundation for the application of the UN Watercourse Convention in the Nile Basin, based on the principles of equitable and reasonable use.

This Special Issue effectively highlights the significant complexities and governance challenges of managing water resources in large river basins. It highlights how disruptive technologies can help to address complex data and analytical challenges, as well as supporting effective participatory decision making over contested water resources. These aspects are illustrated by a selection of diverse case studies. Technology, however, clearly cannot solve all the governance challenges at play, and careful consideration and deployment of deliberative governance and dialogue processes are required to navigate the complexity of water politics in large river basins. This is especially the case in international transboundary river basins of high economic, environmental and political significance. Furthermore, while both hard and soft measures can deliver benefits, neither are sufficiently effective when applied alone. Effective water management in large basins requires progress in both domains and resource managers should increasingly seek to exploit synergies between technology and governance innovations.

Author Contributions: The two authors made equal contributions to this editorial. All authors have read and agreed to the published version of the manuscript.

Funding: This research received no external funding.

Acknowledgments: The authors appreciate the efforts of the Water editors and publication team at MDPI and the anonymous reviewers for their invaluable comments.

Conflicts of Interest: The authors declare no conflict of interest.

\section{References}

1. UNEP-DHI; UNEP. Transboundary River Basins: Status and Trends; United Nations Environment Programme (UNEP): Nairobi, Kenya, 2016.

2. United Nations. Sustainable Development Goal 6 Synthesis Report on Water and Sanitation; United Nations: New York, NY, USA, 2018.

3. Harshadeep, N.R.; Young, W. Disruptive Technologies for Improving Water Security in Large River Basins. Water 2020, 12, 2783. [CrossRef]

4. Dandridge, C.; Fang, B.; Lakshmi, V. Downscaling of SMAP Soil Moisture in the Lower Mekong River Basin. Water 2020, 12, 56. [CrossRef]

5. Zhao, M.; Huang, S.; Huang, Q.; Wang, H.; Leng, G.; Liu, S.; Wang, L. Copula-Based Research on the Multi-Objective Competition Mechanism in Cascade Reservoirs Optimal Operation. Water 2019, 11, 995. [CrossRef] 
6. Simonov, E.A.; Nikitina, O.I.; Egidarev, E.G. Freshwater Ecosystems versus Hydropower Development: Environmental Assessments and Conservation Measures in the Transboundary Amur River Basin. Water 2019, 11, 1570. [CrossRef]

7. van der Vat, M.; Boderie, P.; Bons, K.C.A.; Hegnauer, M.; Hendriksen, G.; van Oorschot, M.; Ottow, B.; Roelofsen, F.; Sankhua, R.; Sinha, S.; et al. Participatory Modelling of Surface and Groundwater to Support Strategic Planning in the Ganga Basin in India. Water 2019, 11, 2443. [CrossRef]

8. O'Sullivan, J.; Pollino, C.; Taylor, P.; Sengupta, A.; Parashar, A. An Integrative Framework for Stakeholder Engagement Using the Basin Futures Platform. Water 2020, 12, 2398. [CrossRef]

9. Foran, T.; Penton, D.J.; Ketelsen, T.; Barbour, E.J.; Grigg, N.; Shrestha, M.; Lebel, L.; Ojha, H.; Almeida, A.; Lazarow, N. Planning in Democratizing River Basins: The Case for a Co-Productive Model of Decision Making. Water 2019, 11, 2480. [CrossRef]

10. Barua, A.; Deka, A.; Gulati, V.; Vij, S.; Liao, X.; Qaddumi, H.M. Re-Interpreting Cooperation in Transboundary Waters: Bringing Experiences from the Brahmaputra Basin. Water 2019, 11, 2589. [CrossRef]

11. Gari, Y.; Block, P.; Assefa, G.; Mekonnen, M.; Tilahun, S.A. Quantifying the United Nations' Watercourse Convention Indicators to Inform Equitable Transboundary River Sharing: Application to the Nile River Basin. Water 2020, 12, 2499. [CrossRef]

Publisher's Note: MDPI stays neutral with regard to jurisdictional claims in published maps and institutional affiliations.

(C) 2020 by the authors. Licensee MDPI, Basel, Switzerland. This article is an open access article distributed under the terms and conditions of the Creative Commons Attribution (CC BY) license (http://creativecommons.org/licenses/by/4.0/). 